Int. J. Dev. Biol. 57: 535-543 (2013)

doi: $10.1387 / \mathrm{ijdb} .130240 \mathrm{qw}$

\title{
Fluorescent protein marker lines in maize: generation and applications
}

\author{
QINGYU WU1', ANDING LUO², TARA ZADROZNY', ANNE SYLVESTER ${ }^{2}$ and DAVE JACKSON*,1 \\ ${ }^{1}$ Cold Spring Harbor Laboratory, NY, and ${ }^{2}$ Department of Molecular Biology, University of Wyoming, Wyoming, USA
}

\begin{abstract}
Fluorescent proteins (FP) have significantly impacted the way that we study plants in the past two decades. In the post-genomics era, these FP tools are in higher demand by plant scientists for studying the dynamics of protein localization, function, and interactions, and to translate sequence information to biological knowledge that can benefit humans. Although FP tools have been widely used in the model plant Arabidopsis, few FP resources have been developed for maize, one of the most important food crops worldwide, and an ideal species for genetic and developmental biology research. In an effort to provide the maize and cereals research communities with a comprehensive set of FP resources for different purposes of study, we generated more than 100 stable transformed maize FP marker lines, which mark most compartments in maize cells with different FPs. Additionally, we are generating driver and reporter lines, based on the principle of the pOp-LhG4 transactivation system, allowing specific expression or mis-expression of any gene of interest to precisely study protein functions. These marker lines can be used not only for static protein localization studies, but will be useful for studying protein dynamics and interactions using kinetic microscopy methods, such as fluorescence recovery after photobleaching (FRAP), fluorescence correlation spectroscopy (FCS), and fluorescence resonance energy transfer (FRET). All of the constructs and maize marker lines are publicly available through our website, http://maize. jcvi.org/cellgenomics/index.php
\end{abstract}

KEY WORDS: fluorescent protein, FRET, maize, pOp, LhG4

\section{Introduction}

Maize, one of the most important crops worldwide, has contributed unparalleled value to genetic research. Advances in maize genomics, including a sequenced genome, have further facilitated maize research in recent years. However, a continuing challenge is to convert a sequence catalog into the knowledge required to improve maize as an important crop for human benefit. One of the most effective approaches to achieve this goal is to understand the spatial and temporal complexity of biological pathways, requiring a knowledge of the dynamics of protein localization, functions and interactions. However, studies in these research areas in maize have not advanced as rapidly as in other systems, in part because of the lack of appropriate tools. Traditionally, static visualization procedures, such as immunolocalization and in situ hybridization have been applied on a small scale (Jackson, 2002). As the capacity and quality of maize transformation has improved, we are now able to use fluorescent proteins (FPs) as an invaluable tool to study the dynamics of protein expression, thus bridging the gap between the genome sequence and protein function.

FPs have significantly impacted biological research over the past decades, since the first FP, Aequorea victoria green fluorescent protein (AvGFP), was discovered in the early 1960s as a companion protein to aequorin from jellyfish (Rizzo et al., 2009, Shimomura et al., 1962). The cDNA of GFP was cloned several decades later in 1992; however, the potential of GFP as a molecular probe in virtually any species was not fully recognized until 1994, when it was demonstrated that GFP driven by a neuron specific promoter in Caenorhabditis elegans marked the site of gene expression (Chalfie et al., 1994, Rizzo et al., 2009). GFP has thereafter been

\footnotetext{
Abbreviations used in this paper: FACS, fluorescence activated cell sorting; FCS, fluorescence correlation spectroscopy; FCCS, fluorescence cross-correlation spectroscopy; FLIM, fluorescence-lifetime imaging microscopy; FLIP, fluorescence loss in photobleaching; FP, fluorescent protein; FRAP, fluorescence recovery after photobleaching; FRET, fluorescence resonance energy transfer; FT, flowering locus T; GT1, grassy tillers 1; SBT, spectral bleed through; SPB, squamosa promoterbinding; TSH1, tassel sheath 1; TU1, tunicate 1 .
}

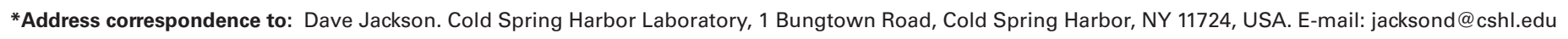


engineered to produce a vast number of spectrally distinct mutants with improved folding and stability properties. Now, with the identification of FPs from other species, scientists can choose from a broad range of FP variants that spans nearly the entire visible spectrum for many applications (Rizzo et al., 2009).

The use of FPs has revolutionized plant biology just as it has other fields, but plant research faced several specific challenges to use them effectively (Jones et al., 2012). Initially, wild-type GFP expression was problematic in plant cells (Hu and Cheng, 1995, Niedz et al., 1995, Sheen et al., 1995). Haseloff and colleagues reported that the expression of GFP in plant cells was hampered by aberrant splicing of wild-type gfp mRNA, due to a cryptic intron between nucleotides 380 and 463 (Haseloff etal., 1997). Thereafter, an optimized GFP variant for plant cells, mGFP5 was produced and widely applied in plant research (Harper et al., 1999, Haseloff et al., 1997). Another challenge for plant applications was the brightness and color of FPs. For example, chlorophyll and stressinduced phenolics autofluoresce are at the same wavelength as many FPs, requiring higher signal intensity or spectral variants (Jones et al., 2012).

In an effort to provide the plant community with a set of common sub-cellular compartment markers with different colors and improved brightness, we have generated a set of maize marker lines containing different proteins with a wide range of codon optimized FPs. In this review, we describe the methods used to generate these stable maize marker lines, and discuss how the lines can help us pursue basic questions in plant biology concerning the dynamic spatial and temporal control of gene expression at a genome-wide level.

\section{Generation of fluorescent protein marker lines}

\section{Generation of protein tagged lines}

We developed a pipeline to generate fusion proteins with different color variants of FPs in the context of each gene's native regulatory elements (Mohanty et al., 2009). All the FP variants are tested to ensure proper expression in maize cells, and some have been maize codon optimized. Table 1 lists the properties of these optimized FP variants used in our maize marker lines. Among the list, the most common FP we used to tag proteins is Citrine FP, a YFP variant which is brighter and more resistant to photobleaching, acidic $\mathrm{pH}$, and other environmental effects than EYFP (Griesbeck et al., 2001). We incorporate significant upstream sequences,

TABLE 1

\section{PROPERTIES OF THE FLUORESCENT PROTEIN VARIANTS} USED IN MAIZE MARKER LINES

\begin{tabular}{|c|c|c|c|c|c|}
\hline Color & FPs & $\begin{array}{l}\text { Excitation } \\
\text { max. }(\mathrm{nm})\end{array}$ & $\begin{array}{l}\text { Emission } \\
\text { max. }(\mathrm{nm})\end{array}$ & Brightness* & References \\
\hline Blue & TagBFP & 402 & 457 & 32.8 & Subach et al., 2008 \\
\hline \multirow[t]{3}{*}{ Cyan } & ECFP & 433 & 475 & 13 & Tsien, 1998 \\
\hline & Cerulean & 433 & 475 & 26.7 & Rizzo et al., 2004 \\
\hline & mTFP1 & 462 & 492 & 54.0 & Ai et al., 2006 \\
\hline Green & EGFP & 488 & 507 & 33.6 & Cormack et al., 1996 \\
\hline Yellow & Citrine YFP & 516 & 529 & 58.5 & Griesbeck et al., 2001 \\
\hline Orange & $\begin{array}{l}\text { TdTomato } \\
\text { TagRFP-T }\end{array}$ & $\begin{array}{l}554 \\
555\end{array}$ & $\begin{array}{l}581 \\
584\end{array}$ & $\begin{array}{l}95.2 \\
33.2\end{array}$ & $\begin{array}{l}\text { Shaner et al., } 2004 \\
\text { Shaner et al., } 2008\end{array}$ \\
\hline Red & $\begin{array}{l}\text { mRFP1 } \\
\text { mCherry }\end{array}$ & $\begin{array}{l}584 \\
587\end{array}$ & $\begin{array}{l}607 \\
610\end{array}$ & $\begin{array}{l}6.27 \\
15.8\end{array}$ & $\begin{array}{l}\text { Campbell et al., } 2002 \\
\text { Shaner et al., } 2004\end{array}$ \\
\hline
\end{tabular}

*Brightness is the product of extinction coefficient and quantum yield, divided by 1000 . including the promoter and associated regulatory regions, introns, and 3' sequences for each FP tagged gene, to promote native expression level and localization in a tissue and developmentallyspecific manner. The Multisite Gateway Pro (Invitrogen, Carlsbad, CA, USA) system is used to generate full genomic sequence with the FP insert, which is flanked by linker peptides to minimize folding interference between the FP and tagged protein. The FPs are either fused as N-terminal, C-terminal, or internal tags, according to protein functional domain analysis, to ensure the fusion proteins retain their native functions. After confirming the constructs by sequencing, Agrobacterium-mediated transformation of maize is performed at the lowa State University Plant Transformation Facility using Hill embryos (Armstrong et al., 1991).

\section{Generation of promoter marker lines}

Our work with protein fusions in a genomic construct allowed us to learn about the complexity of maize promoters. The maize genome is large, often with nested transposable element arrays between genes, and it was not clear whether the 2 or $3 \mathrm{~kb}$ of sequence immediately upstream of the coding region would be sufficient to drive the correct expression pattern. We have tested this for a number of genes, and determined in several cases a 2 or $3 \mathrm{~kb}$ region is sufficient. We routinely take all of the 5' sequence up to the first retrotransposon, because PCR amplification within a transposon repeat is usually not feasible. Examples of promoters driving tissue or cell specific expression are shown in Fig. 1.

\section{Generation of pOp-LhG4 transactivation marker lines}

The pOp-LhG4 transactivation system has been used for cellular and developmental studies in different species such as Arabidopsis, tobacco and tomato, and has also been used in maize (Craft et al., 2005, Fernandez et al., 2009, Rutherford et al., 2005, Segal et al., 2003). The pOp-LhG4 system includes 1) a chimeric promoter, pOp, that consists of lac operators cloned upstream of a minimal CaMV promoter and 2) a transcription activator, LhG4, which is a fusion between a high-affinity DNA-binding mutant of lac repressor, $\mathrm{Lacl}^{\mathrm{His} 17}$, and transcription-activation-domain-II of GAL4 from Saccaromyces cerevisiae (Samalova et al., 2005). The pOp promoter is not activated in the reporter lines until crossed with activator lines that express LhG4 driven by appropriate tissuespecific promoters (Samalova et al., 2005). Thus, the pOp-LhG4 transactivation system allows specific expression or mis-expression of any gene of interest. Using our experience with maize promoters described above, we are now developing such tools in maize to allow precise experimental intervention to study gene function (Fernandez et al., 2009, Gardner et al., 2009, Goll et al., 2009, Jones, 2009, Moore et al., 2006).

We are generating cell, tissue or developmental-stage specific promoter transactivation lines based in part on sequence information learned from our translational fusions. Each selected promoter is amplified and Gateway cloned into a derivative of our standard maize binary vector, upstream of the LhG4 gene. The same backbone vector includes a pOp reporter to allow for screening of driver constructs in the T0 generation without the need to cross to reporter lines, which is time consuming. The pOp sequences can drive expression bi-directionally (Fig. 2), and can therefore transactivate two reporters simultaneously. We took advantage of this by making a GUS $<<$ pOp $>>$ NLS-TagRFP-T (Shaner et al., 2008) reporter (Fig. 2). "NLS" refers to tandem nuclear localiza- 

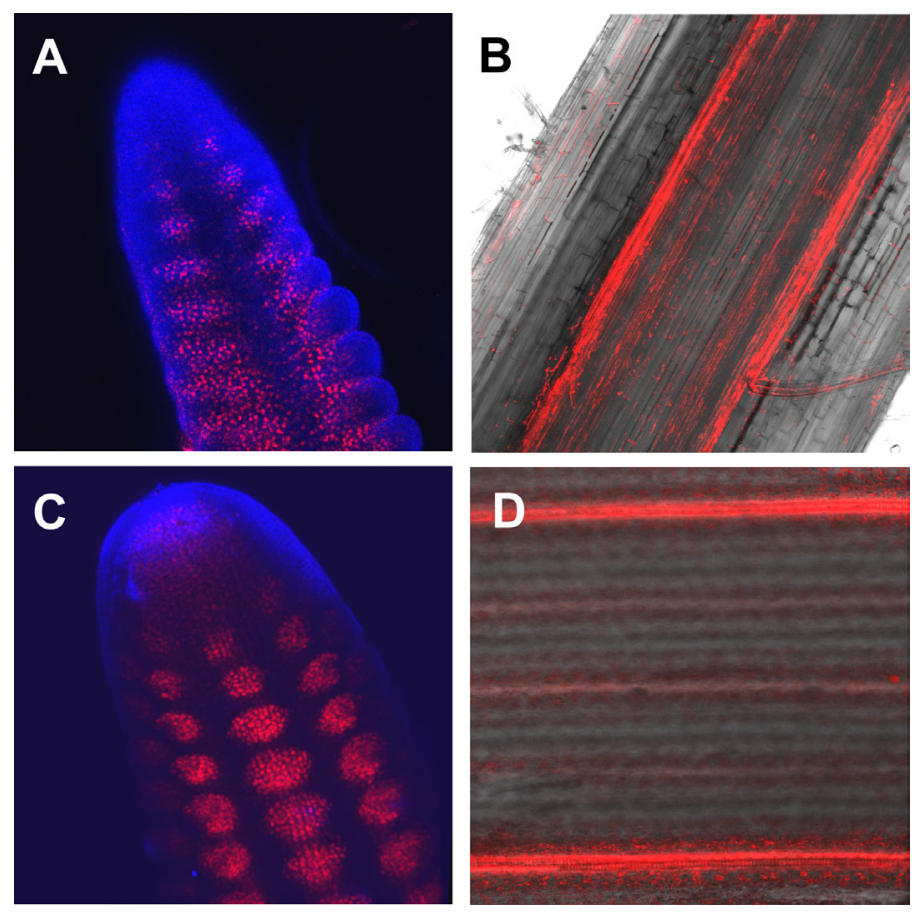

Fig. 1. Images show tissue specific expressions of some maize promoters. Expression of pRAMOSA3::NLS-TagRFP-T at the base of spikelet meristems (A), pSUCROSETRANSPORTER 1 (SUT1)::RFP in root vascular tissue (B), pWUSCHEL::NLS-TagRFP-T in spikelet meristems (C), and pSUCROSE TRANSPORTER 1 (SUT1)::RFP in leaf vascular tissue (D).

tion sequences that were added to ensure cell autonomy of the TagRFP-T protein (Goldshmidt et al., 2008). The two reporters will be inherited in cis, so that either GUS or NLS-TagRFP-T expression can be used to verify driver specificity. GUS staining can be used for imaging in tissues that are highly auto-fluorescent (eg. mature tissues), whereas NLS-TagRFP-T can be used for non-invasive imaging of living tissues. Use of TagRFP-T further distinguishes chlorophyll auto-fluorescence, because its emission peak of $\sim 620$ $\mathrm{nm}$ (Shaner et al., 2008) will facilitate separation from chlorophyll autofluorescence, at $\sim 650-680 \mathrm{~nm}$ (Billinton and Knight, 2001). Another advantage of using TagRFP-T is the potential to distinguish it from our lines already tagged with mRFP1 or mCherry (Shaner et al., 2005). Even though the driver lines always have the TagRFP-T reporter, users will still be able to observe expression of a distinct FP fusion in the reporter lines using a contrasting color FP tag.
Besides the driver lines, we are also generating a set of reporter constructs for transactivaton, driven by a multimeric $p O p$ sequence. These reporters will enhance the utility of the promoter driver lines by allowing us to confirm their specificity. For example, we generated a maize pOp:: ZCN8, a FLOWERING LOCUS T (FT)-LIKE gene in maize (Meng et al., 2011), to permit flexible control of the expression of ZCN8 and studying the maize flowering process. Similarly we are generating a responder for the LIGULELESS1 gene that encodes a novel protein with a domain similar to a SQUAMOSA PROMOTER-BINDING (SPB) protein (Moreno et al., 1997) and a pOp line that drives an auxin biosynthesis gene. More promoter and driver lines are being constructed for diverse uses, including complementation tests of mutants to test for cell autonomy, tissue specific knockouts for genes that are lethal as nulls, cell/ tissue ablation, and fluorescence activated cell sorting (Birnbaum et al., 2005). All the constructs, seed stocks and images are publicaly avaible through our website http://maize.jcvi. org/cellgenomics/index.php.

\section{Application of fluorescent protein marker lines}

\section{Application of fluorescent protein marker lines in protein localization studies}

FPs have become an indispensable tool for studying protein localization in living organisms, tissues, and cells because their ability to be cloned into any open reading frame enables real time in vivo imaging of tissue specificity, sub-cellular localization and dynamics. In the past, using FPs to study protein localization relied on transient expression in protoplasts, in $N$. benthamiana leaves or onion epidermal cells, due to the laborious nature of stable transformation. However, the physiological and developmental condition of cells used in transient assays in other organisms can differ significantly from their native cells or tissues in the whole plant, thus potentially influencing protein localization and dynamics and heterologous expression reduces the reliability of the results. To advance use of our FP resource, we developed a robust transient expression system in maize that reduces complications from heterologous expression in these systems (Kirienko et al., 2012). A practical advantage of maize transient expression for FP studies is the ability to test constructs prior to stable transformation. Further, co-bombardment and use of transient assays in stable lines using contrasting color markers, and experimental studies significantly advance the FP resource.

The transient assay system in maize expands the uses of our

\section{cis}

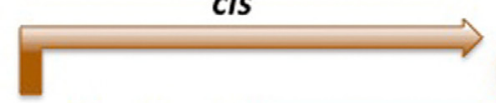

Promoter LhG4 (3') $\quad$ GUS $<p O p>$ NLS-RFP

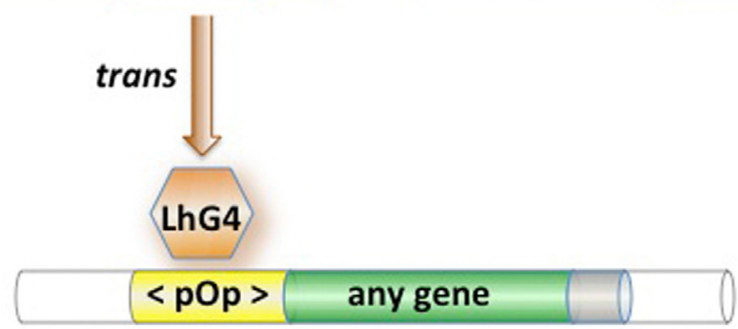

Fig. 2. pOp-LhG4 transactivation system in maize. A tissue specific promoter drives expression of the LhG4 transcription factor, which binds to $\mathrm{pOp}$ sequences and activates expression of GUS and NLS-tagRFP-T in the same cells. This line can also be crossed to any otherpOp reporter line, to activate any gene in trans. 
FP lines; however stable transformation remains the gold standard for studying protein function in vivo. As an example, Bommert et al. (2013) showed that a functional YFP tagged maize $G$ alpha protein is highly expressed in shoot meristems, and using the YFP tag for immunoprecipitation could demonstrate an interaction between $\mathrm{G}$ alpha and the CLAVATA LRR receptor FASCIATED EAR2. In a second example, by tagging a YFP to the C-terminus of the protein, Whipple et al., (2011) showed that GRASSY TILLERS1 (GT1), a class I HD-Zip that controls lateral branching in maize, localizes to the nucleus and expresses in the leaves of axillary buds (Whipple et al., 2011). In addition, using RFP and YFP tags, Han et al., (2012) showed nuclear localization of TUNICATE1 (TU1), a MADS box transcription factor, in leaf primordia. In the dominant Tu1 mutant, expression was also observed at the base of spikelet pair meristems, which helps explain the dominant phenotype. In fact, use of the FP fusions was instrumental in proving that the candidate MADS box gene was responsible for the Tu1 mutation (Han et al., 2012). In another example, Whipple et al., (2010) showed that a YFPtagged TASSEL SHEATH 1 (TSH1), which is a zinc-finger protein controlling maize bract growth, displays the strongest fluorescence in the basal-most bracts subtending tassel branch promordia, matching the localization pattern of the Tsh1 transcript (Whipple et al., 2010). This result indicates that unlike some developmental transcription factors, the TSH1 protein probably does not traffic from cell to cell (Whipple et al., 2010). In other examples, stably transformed maize lines expressing FP fusion proteins have also been used to study biosynthetic proteins (Christensen et al., 2013, Falcone Ferreyra et al., 2012) and proteins that regulate asymmetric cell divisions during leaf development (Humphries et al., 2011, Zhang et al., 2012). Transcriptional fusions have also been used to make hormone responsive reporters (Lee et al., 2009). All of these studies suggest that FP reporters are powerful tools to study protein localization and tissue specificity, especially after being stably transformed into maize plants.

In order to provide the maize community with resources for protein localization and tissue specificity studies, we have generated a set of FP tagged marker lines which mark most compartments in maize cells with different FPs using the pipline described above. Fig. 3 shows several images from different compartment markers in maize. All the constructs and seeds are available by request through our website at http://maize.jcvi.org/cellgenomics/index.php.

\section{Application of fluorescent protein marker lines in cell specific gene expression studies using fluorescence activated cell sorting (FACS)}

Cell-specific resolution of gene activity is critical to understand specific developmental events (Birnbaum et al., 2005). However, such high resolution data have been difficult to obtain at a genomic level because specific types of cell need to be isolated (Birnbaum et al., 2005). One of the most efficient ways to isolate specific cells of interest from neighboring cells in the same organ or tissue is FACS, which sorts FP-labeled protoplasted cells on the basis of their fluorescence (Afonso et al., 1985). The isolated cells can be used for subsequent genomic analsis. The FACS-based genomic approach has been sucessfully applied for developmental research in Arabidopsis. For example, Benfey and colleagues have mapped gene expression profiles of specific root zones, corresponding to various cell types and tissues at different developmental stages, using a combination of FACS and microarray analysis (Birnbaum et al., 2003). Further discussion about the application of FACS in plants can be found in the review by Carter et al., in this issue (Carter et al., 2013).

Although FACS has been succesfully used in Arabidopsis, a lack of tissue or cell specific promoters has minimized the use of FACS in maize. Until recently, there were only a few specific promoters defined in maize (Cao et al., 2007, Sattarzadeh et al., 2009, Srilunchang et al., 2010, Zhang et al., 2009). We generated a set of promoter-FP direct fusion marker lines, which can be used for FACS experiments. For example, we generated pWUSCHEL::NLS-RFP and pRAMOSA3::NLS-RFP lines, and these direct fusions will facilitate gene profiling of the maize shoot by marking different regions of the meristem. In addition, we are currently generating more LhG4 driver lines, which can also be useful for FACS applications.

\section{Live cell imaging using fluorescent protein markers}

Live cell imaging is a powerful tool for observational and experimental studies of plant development in real time and in 3D. Such studies trace back historically to 3D reconstructions of fixed images at sequential time points, which were used to understand basic subcellular architecture in plants (Donohoe et al., 2013, Staehelin, 1997). Live imaging of FP lines now permits experimental studies of whole organ growth, interactions among neighboring cells, behavior of individual cytoskeletal elements and the ability to trace movement of proteins between cells (Grossmann et al., 2012, Gutierrez et al., 2009, Krebs et al., 2012, Lindeboom et al., 2013, Mathur et al., 2012, Sampathkumar et al., 2011, Teh et al., 2013). With the advent of microfluidic devices, FP markers can be used as biosensors for hormone induction studies during whole root or shoot growth. Computational modeling of plant growth responses has become more powerful and informative because simulations can be guided by in vivo observations, and then the modeled outcomes further tested in vivo for validation (Robinson et al., 2011). In some cases, the FP provides an important cellular marker regardless of its specific function in the cell (Robinson et al., 2011). In other cases, the FP tagged protein is studied functionally during live cell imaging (Cunha et al., 2012). In one example, responses of microtubule arrays to deformation or damage of neighboring cells was studied in vivo by live cell imaging over time, and reconstructions showed reorientations of microtubule cortical arrays upon perturbation (Heisler et al., 2010). For maize, visual FP tools will be a dynamic tool for cell biology studies through live cell imaging. Furthermore, study of single molecule function demands the use of live cell imaging techniques best accomplished using FPs, as described in the next section.

\section{Application of fluorescent protein marker lines in protein dynamics studies}

In addition to live cell imaging of growth, FP technology enables an investigation of protein dynamics in living cells and single molecule studies. Several quantitative fluorescence spectro-microscopy approaches such as fluorescence recovery after photobleaching (FRAP), fluorescence loss in photobleaching (FLIP), and Fluorescence correlation spectroscopy (FCS) have been used for protein dynamic studies in plants (Field et al., 2010, Grossmann et al., 2012, Harter et al., 2012, Hoover et al., 2010). Other techniques such as dual-color fluorescence cross-correlation spectroscopy (FCCS), and fluorescence resonance energy transfer (FRET) have 
been used for protein-protein interaction studies.

FRAP is a powerful technique to quantify the average rate of protein translocation within living cells (Reddy et al., 2007). In a FRAP experiment, fluorescently tagged proteins in an area of the cell are irreversibly photobleached with a high-intensity laser pulse. The movement of fluorescently tagged proteins from surrounding areas into the bleached area is recorded by time-lapse microscopy to estimate protein mobility. FRAP is useful for studying organelle dynamics, protein diffusion within membranes or organelles, or protein turnover in complexes (Fang etal., 2004, Fricker et al., 2006, Kwok and Hanson, 2004, Runions et al., 2006). For example, the factors that influence protein traffic from the ER to Golgi apparatus have been studied using FRAP (Brandizzi et al., 2002, DaSilva et al., 2004, Yang et al., 2005). In addition, Luu and colleagues recently used FRAP to estimate the cycling of aquaporin between intracellular compartments and the cell surface under salt stress conditions (Luu et al., 2012). The results showed that the recovery of fluorescence of GFP tagged aquaporin increased 1.3-1.5 fold under salt stress as compared with the values for control, suggesting that salt treatment enhances the cycling of aquaporin (Luu et al., 2012). All of these studies demonstrate that FRAP is a powerful tool to investigate protein dynamics. However, if the goal of the experiment is to determine total connectivity within an extended membrane system, such as the ER, a similar technique termed FLIP is generally chosen (Fricker et al., 2006, Ward and Brandizzi, 2004). FLIP is performed by continuous photobleaching FPs in one area of the cell to drain signal from all connected compartments. By monitoring the fluorescence in the non-photobleached regions, the mobility and connectivity of a fluorescently tagged protein within the membrane can readily be observed (Lippincott-Schwartz and Patterson, 2003, Nehls et al., 2000). FLIP successfully demonstrated protein movement from one plastid to another via long tubular extensions referred to as stromules (Hanson et al., 2007).

FCS is another sensitive fluorescence technique used for the study of diffusion rate of fluorescent molecules, and can also determine if proteins are in a complex (Hink et al., 2002). FCS measures fluorescent intensity fluctuations due to movement of single fluorescent molecules in and out of a small defined focal volume over short periods of time (Goedhart et al., 2000). This technique has been routinely used to obtain information of a protein's diffusion coefficient, binding constant, and concentrations within a living cell by correlating the fluorescent fluctuations over time (Reddy et al.,
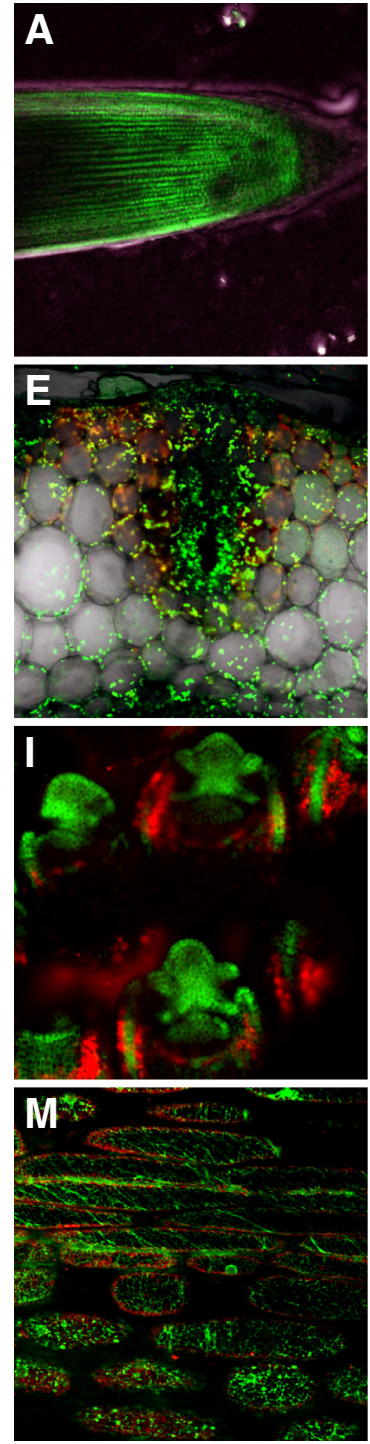
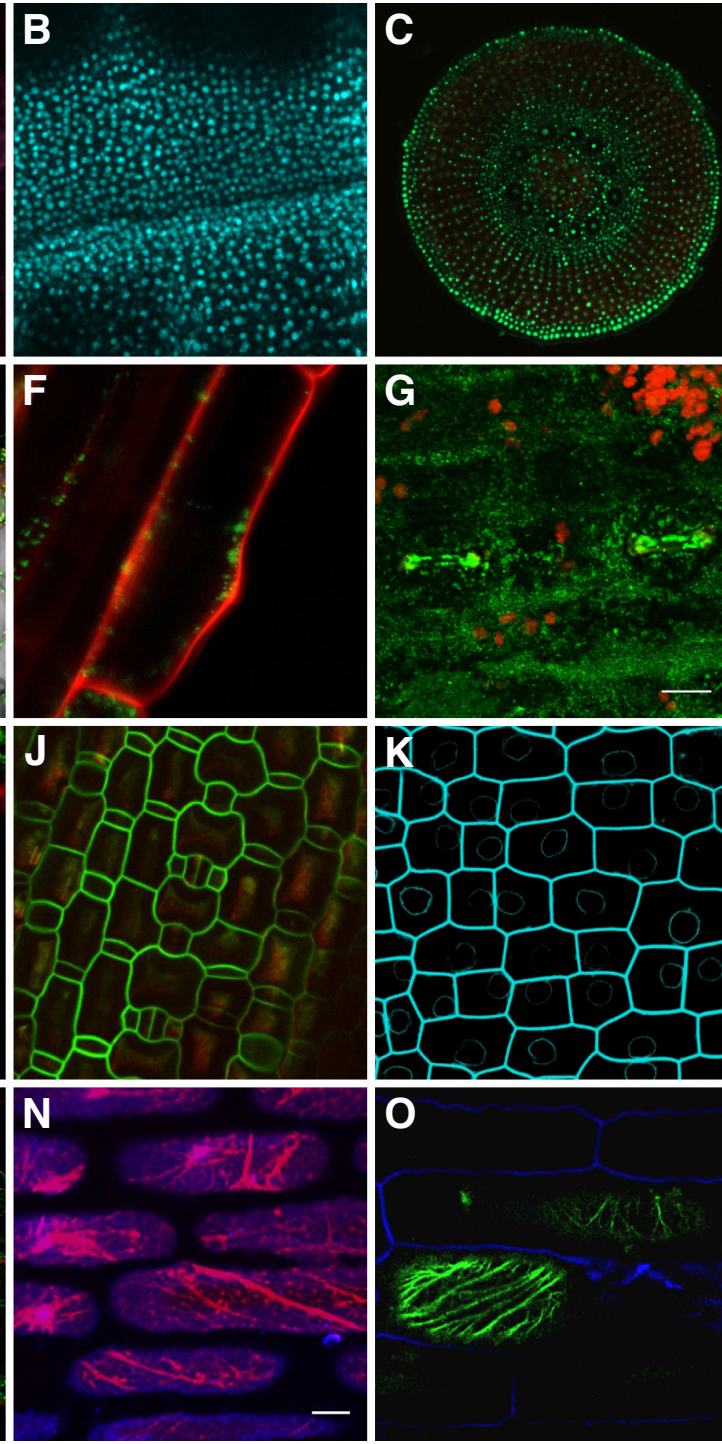
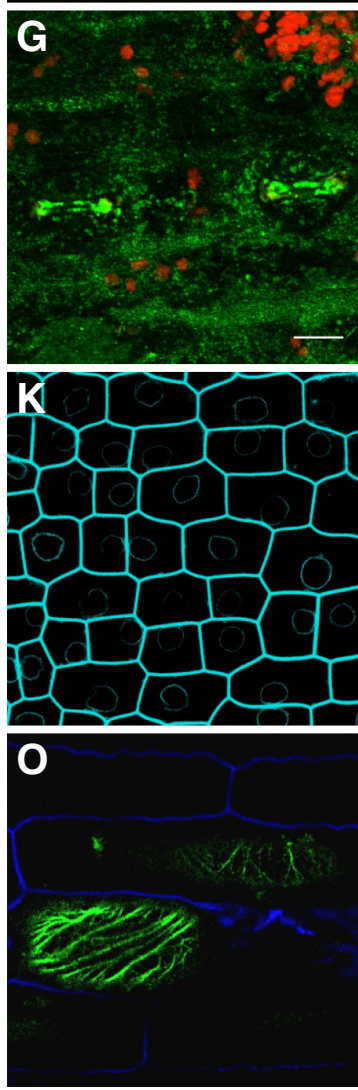
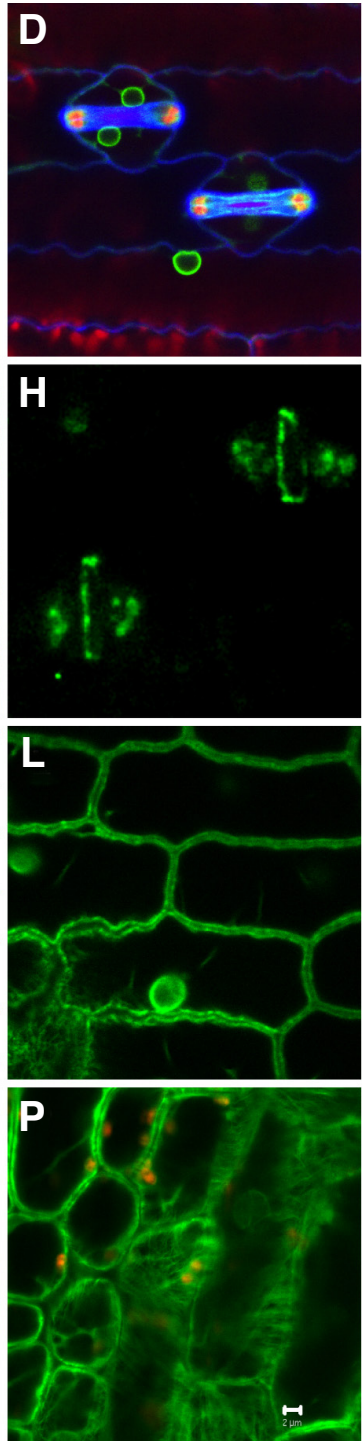

Fig. 3. Subcellular localization of expressed FP-tagged maize proteins. (A) DECREASE IN DNA METHYLATION 1-YFP, nuclei, root. (B) LIGULELESS 2-mTFP, nuclei, leaf. (C) HISTONE H1-YFP, nuclei, root transverse section. (D) RANGAP-YFP, nuclear envelope, leaf epidermis. (E) MALATE DEHYDROGENASE-YFP, mesophyll chloroplasts, leaf. (F) PEROXIN11-YFP, peroxisome, root. (G) Heat Shock Protein22YFP; mitochondria, leaf. (H)TANGLED1-YFP, preprophase band, leaf. (I) PINFORMED1-YFP, plasma membrane, ear floral meristem. (J) PINFORMED1YFP, plasma membrane, leaf. (K) PIP2-1-CFP, plasma membrane, leaf. (L) TONOPLAST INTRINSIC PROTEIN1-YFP, vacuole membrane and $E R$, leaf. (M) PROTEIN DISULFIDE ISOMERASE-YFP, ER, leaf. (N) FLAVONOL SYNTHASE1-RFP, $E R$, leaf. (O) FIMBRIN ACTIN BINDING DOMAIN-YFP, actin cytoskeleton, leaf. (P) $\alpha$-TUBULIN-YFP, microtubules, leaf. 
2007). For example, using FCS, Goedhart et al., (2000) examined the diffusion of fluorescent Nod factor analogues on living Vicia sativa root hairs (Goedhart et al., 2000). The results suggest that the fluorescently labeled Nod factor have a >1000-fold reduction of mobility upon binding to the cell wall, indicating the molecules are tightly bound to a specific receptor located in the cell wall (Goedhart et al., 2000). FCS can also be used in living cells to study diffusion velocity. For example, Kohler et al., (2007) showed that the diffusion velocity of GFP within plastid tubules is 50 times slower than within the cytosol (Kohler et al., 2000).

\section{Application of fluorescent protein marker lines in protein interaction studies}

Although FCS is a powerful technique to study protein dynamics, it is difficult to discriminate small mass changes of fluorescent molecules (Hink et al., 2002). For example, Meseth and colleagues have pointed out that the resolving power of FCS is a four-fold mass increase, indicating that a homo-dimer cannot be detected by FCS (Meseth et al., 1999). FCCS is a technique that overcomes the limitation of FCS, by tagging candidate proteins with two different fluorophores (Schwille et al., 1997). FCCS can evaluate the molecular interaction between two spectrally distinct molecules in a quantitative manner. If two labeled molecules bind together, the cross-correlation between the fluctuations in fluorescence intensity of the two molecules would be strong. FCCS has been used to study the interaction between Arabidopsis auxin response factors and their Aux/IAA repressors in a quantitative manner by transiently expressing the fluorescently tagged proteins in HeLa cells (Muto et al., 2006). One advantage over FRET methods is that FCCS is not affected by the relative orientation between the donor and acceptor fluorophores, or by the distance between them (Muto et al., 2009). However, some other factors, such as cellular autofluorescence, photobleaching of the dye, cell damage, and reduced signal-to noise ratios have limited the application of FCS and FCCS in living cells, especially in plant cells (Hink et al., 2003). These problems can be partially resolved by developing FPs with high brightness and photostability. FCCS holds great promise for analyzing protein-protein interaction and protein dynamics in living plant cells.

FRET is another widely used technique to detect dynamic protein-protein interactions in vivo. The principle of FRET is that energy from an excited donor molecule is transferred to an acceptor molecule, when the donor fluorescence overlaps with the absorption spectrum of the acceptor, and when both molecules are in close proximity (between 2 and $10 \mathrm{~nm}$ ) (Zelazny et al., 2007). There are two major FRET measurement methods, intensity-based and life-time based (Dixit et al., 2006). The most commonly used intensity-based method is the sensitized emission measurement (Sun et al., 2009). This approach requires the identification and removal of the spectral bleed through (SBT) components from FRET signals (Sun et al., 2009), and the FRET efficiency is calculated using total donor and corrected FRET (Wallrabe and Periasamy, 2005). Thus, the results using sensitized methods are affected by the relative fluorescent intensities of donor and receptor (Hink et al., 2002). In contrast, the life-time based method, fluorescence-lifetime imaging microscopy (FLIM), is independent of the concentration of both the acceptor and the donor and insensitive to photobleaching, and is becoming more popular in plant research (Miyawaki, 2011). In FRET-FLIM experiments, the interaction of two proteins can be confirmed by monitoring the reduction of fluorescence lifetime of the donor, because the excited lifetime of the donor is attenuated through transferring energy to the acceptor (Dixit et al., 2006). FRET-FLIM has been used to quantitatively and dynamically detect protein-protein interactions in living plant cells. For example, Immink et al., (2002) applied FRET-FLIM to study the interaction of MADS box transcription factors in petunia protoplasts (Immink et al., 2002). All petunia MADS box heterodimers identified in yeast two-hybrid systems have been confirmed using FRET-FLIM. Additionally, homodimerization of three petunia MADS box proteins has been identified in this study (Immink et al., 2002). Another very interesting research approach using FRET-FLIM characterized the interaction between two receptor kinases, CLAVATA 1 (CLV1) and ARABIDOPSISCRINKLY4 (ACR4), in the plasma membrane (PM) and plasmodesmata (PD) (Stahl et al., 2013). Their FRET-FLIM analyses demonstrated that ACR4 and CLV1 form homomeric and heteromeric complexes with distinct stoichiometries or conformations, depending on their locations in PM or PD (Stahl et al., 2013). FRET-FLIM has also been applied in maize research using maize protoplasts. Zelazny et al., (2007) showed that the maize aquaporin $\mathrm{ZmPIP1}$ is retained at the endoplasmic reticulum; however, it relocalizes to the plasma membrane in the presence of another aquaporin, ZmPIP2 (Zelazny et al., 2007). The FRET-FLIM result suggests that ZmPIP1 and ZmPIP2 relocalization results from their physical interaction (Zelazny et al., 2007). All of these experiments are elegantly designed; however, it will be more convincing to conduct FRET experiments using the native tissues that express fluorescently tagged proteins driven by their endogenous promoters. Potential artifacts can arise due to overexpression, as well as the physiological condition of protoplasts and differences that can arise from heterologous expression in unrelated species. This may influence signaling cascades, and hence protein-protein interactions (Hink et al., 2003). However, factors such as the autofluorescence from the cell wall, or the relative lower expression caused by use of a native promoter, may hamper the use of FRET experiments in stable lines.

Most disadvantages of FRET in stable lines can be circumvented by improvement of the quality of FP tags. CFP and YFP are the most commonly used fluorescent protein pair for FRET experiments. However, this pair is far from ideal, because the quantum yield of CFP is low, and thus requires high excitation intensity, causing cell damage (Bayle et al., 2008). Additionally, YFP originally had a slow maturation rate and high sensitivity to $\mathrm{pH}$. Some of the drawbacks of YFP and CFP were partially resolved by the emergence of improved variants. For example, the Citrine variant of YFP is brighter and more resistant to photobleaching and acidic $\mathrm{pH}$ (Griesbeck et al., 2001), whereas Cerulean, a CFP variant, is twice as bright as CFP (Rizzo et al., 2004). With the growing palette of bright FPs, a variety of new FP combinations for use in FRET experiments have become available (Davidson and Campbell, 2009). For example, mTFP1, a monomeric teal-colored FP from coral, which exhibits higher brightness, acid insensitivity, and photostability than any of the cyan $A$. victoria variants (Ai et al., 2006) has been used for FRET with Citrine (Ai et al., 2008). Some other FRET pairs, such as mAmetrine and tdTomato (Ai et al., 2008), and tSapphire and mOrange (Bayle et al., 2008), have been developed recently. A more comprehensive list of FRET pairs can be found in Day and Davidson's review paper (Day and Davidson, 2012). We have developed a set of codon optimized FPs, such as Cerulean, Citrine, 
mTFP1, mCherry, and stable transformed maize marker lines expressing these FPs to facilitate the investigation of dynamic protein-protein interactions using FRET.

\section{Conclusions}

Use of GFP and its derivatives has revolutionized the way that we study plants. FPs have been extensively engineered to improve their host range and spectral characteristics (Berg and Beachy, 2008, Shaner et al., 2005, Tsien, 2009). Their ability to be cloned into any open reading frame makes them an ideal choice for localization studies on a genomic scale, and enables real time in vivo imaging of tissue specificity, sub-cellular localization and dynamics. When such reporters are combined with a transactivation system to allow specific expression or mis-expression of any gene of interest, it allows for precise experimental intervention to study gene function (Fernandez et al., 2009, Gardner et al., 2009, Goll et al., 2009, Jones, 2009, Moore et al., 2006). We developed a pipeline to generate FP marker lines and transactivation driver and reporter lines in maize. This pipeline could be easily applied to other plants, for example, the new $\mathrm{C}_{4}$ photosynthesis model Setaria viridis (Brutnell et al., 2010), providing a broad-based cell biological resource to the plant biology community. All the information about the constructs, seeds and images can be found in our website http://maize.jcvi.org/cellgenomics/index.php. Currently, the seeds from all direct promoter fusions and most protein tagged lines are available by requesting via our website. The T2 generation seeds of the transactivation system will also be available to the research community in the near future. In addition, all the constructs listed in our website are available to facilitate research in other species, or use in maize transient assays.

These tools in maize will facilitate research of diverse programs. Besides the traditional applications, like protein localization or tissue specificity studies, the stable transformed maize marker lines also hold promise for live imaging microscopy to investigate protein dynamics and interactions in a real-time manner.

\section{Acknowledgements}

The authors would like to thank Holly Steinkraus for lab assistance, maintaining stocks and distribution, Carolyn Rassmussen for cloning assistance and advice, Agnes Chan and Vivik Krishnakumar for contributions of informatics, Stacy DeBlasio and Alexander Goldshmidt for contributions of imaging, Tim Mulligan for excellent plant care at CSHL, Casey Seals and Ryan Pendleton for care of plants at the Agriculture Experiment Station greenhouse complex at the University of Wyoming and Kan Wang, Bronwyn Frame and colleagues at lowa State University for maize transformation services. The grants from the National Science Foundation DBI-0501862 and IOS- 1027445 are greatly acknowledged.

\section{References}

AFONSO, C.L., HARKINS, K.R., THOMASCOMPTON, M.A., KREJCI, A.E. and GALBRAITH, D.W. (1985). Selection of Somatic Hybrid Plants in Nicotiana through Fluorescence-Activated Sorting of Protoplasts. Bio-Technology 3:811-816.

AI, H.W., HAZELWOOD, K.L., DAVIDSON, M.W. and CAMPBELL, R.E. (2008). Fluorescent protein FRET pairs for ratiometric imaging of dual biosensors. Nat Methods 5: 401-403.

AI, H.W., HENDERSON, J.N., REMINGTON, S.J. and CAMPBELL, R.E. (2006). Directed evolution of a monomeric, bright and photostable version of Clavularia cyan fluorescent protein: structural characterization and applications in fluorescence imaging. Biochem J 400: 531-540.
ARMSTRONG, C., GREEN, C. and PHILLIPS, R. (1991). Development and availability of germplasm with high Type II culture formation response. Maize Genet Coop Newsletter 65: 92-93.

BAYLE, V., NUSSAUME, L. and BHAT, R.A. (2008). Combination of novel green fluorescent protein mutant TSapphire and DsRed variant mOrange to set up a versatile in planta FRET-FLIM assay. Plant Physiol 148: 51-60.

BERG, R.H. and BEACHY, R.N. (2008). Fluorescent protein applications in plants Methods Cell Biol 85: 153-177.

BILLINTON, N. and KNIGHT, A.W. (2001). Seeing the wood through the trees: a review of techniques for distinguishing green fluorescent protein from endogenous autofluorescence. Anal Biochem 291: 175-197.

BIRNBAUM, K., JUNG, J.W., WANG, J.Y., LAMBERT, G.M., HIRST, J.A., GALBRAITH, D.W. and BENFEY, P.N. (2005). Cell type-specific expression profiting in plants via cell sorting of protoplasts from fluorescent reporter lines. Nat Methods 2: 615-619.

BIRNBAUM, K., SHASHA, D.E., WANG, J.Y., JUNG, J.W., LAMBERT, G.M., GALBRAITH, D.W. and BENFEY, P.N. (2003). Agene expression map of the Arabidopsis root. Science 302: 1956-1960.

BOMMERT, P. , JE, B.I., GOLDSHMIDT, A. and JACKSON, D. (2013) The maize Ga gene COMPACT PLANT2 functions in CLAVATA signalling to control shoot meristem size. Nature (doi:10.1038/nature12583).

BRANDIZZI, F., SNAPP, E.L., ROBERTS, A.G., LIPPINCOTT-SCHWARTZ, J. and HAWES, C. (2002). Membrane protein transport between the endoplasmic reticulum and the golgi in tobacco leaves is energy dependent but cytoskeleton independent: Evidence from selective photobleaching. Plant Cell 14: 1293-1309.

BRUTNELL, T.P., WANG, L., SWARTWOOD, K., GOLDSCHMIDT, A., JACKSON, D., ZHU, X.G., KELLOGG, E. and VAN ECK, J. (2010). Setaria viridis: a model for C4 photosynthesis. Plant Cell 22: 2537-2544.

CAMPBELL, R.E., TOUR, O., PALMER, A.E., STEINBACH, P.A., BAIRD, G.S., ZACHARIAS, D.A. and TSIEN, R.Y. (2002). A monomeric red fluorescent protein. Proc Natl Acad Sci USA 99: 7877-82.

CAO, X., COSTA, L.M., BIDERRE-PETIT, C., KBHAYA, B., DEY, N., PEREZ, P., MCCARTY, D.R., GUTIERREZ-MARCOS, J.F. and BECRAFT, P.W. (2007). Abscisic acid and stress signals induce Viviparous1 expression in seed and vegetative tissues of maize. Plant Physiol 143: 720-731.

CARTER, A.D., BONYADI, R. and GIFFORD, M.L. (2013). The use of fluorescenceactivated cell sorting in studying plant development and environmental responses. Int. J. Dev. Biol. 57: 545-552 (doi: 10.1387/ijdb.130195mg).

CHALFIE, M., TU, Y., EUSKIRCHEN, G., WARD, W.W. and PRASHER, D.C. (1994). Green Fluorescent Protein as a Marker for Gene-Expression. Science263: 802-805.

CRAFT, J., SAMALOVA, M., BAROUX, C., TOWNLEY, H., MARTINEZ, A., JEPSON, I., TSIANTIS, M. and MOORE, I. (2005). New pOp/LhG4 vectors for stringent glucocorticoid-dependent transgene expression in Arabidopsis. Plant J 41:899-918.

CHRISTENSEN, S.A., NEMCHENKO, A., BORREGO, E., MURRAY, I., SOBHY I.S., BOSAK, L., DEBLASIO, S., ERB, M., ROBERT, C.A., VAUGHN, K.A., et al. (2013). The maize lipoxygenase, ZmLOX10, mediates green leaf volatile, jasmonate and herbivore-induced plant volatile production for defense against insect attack. Plant J 74: 59-73.

CORMACK, B.P., VALDIVIA, R.H. and FALKOW, S. (1996). FACS-optimized mutants of the green fluorescent protein (GFP). Gene 173: 33-38.

CUNHA, A., TARR, P.T., ROEDER, A.H., ALTINOK, A., MJOLSNESS, E. and MEYEROWITZ, E.M. (2012). Computational analysis of live cell images of the Arabidopsis Thaliana plant. Methods Cell Biol 110: 285-323.

DASILVA, L.L.P., SNAPP, E.L., DENECKE, J., LIPPINCOTT-SCHWARTZ, J., HAWES, C. and BRANDIZZI, F. (2004). Endoplasmic reticulum export sites and golgi bodies behave as single mobile secretory units in plant cells. Plant Cell 16: 1753-1771.

DAVIDSON, M.W. and CAMPBELL, R.E. (2009). Engineered fluorescent proteins: innovations and applications. Nat Methods 6: 713-717.

DAY, R.N. and DAVIDSON, M.W. (2012). Fluorescent proteins for FRET microscopy: monitoring protein interactions in living cells. Bioessays 34: 341-350.

DIXIT, R., CYR, R. and GILROY, S. (2006). Using intrinsically fluorescent proteins for plant cell imaging. Plant $J$ 45: 599-615.

DONOHOE, B.S., KANG, B.H., GERL, M.J., GERGELY, Z.R., MCMICHAEL, C.M., BEDNAREK, S.Y. and STAEHELIN, L.A. (2013). Cis-Golgi cisternal assembly and biosynthetic activation occur sequentially in plants and algae. Traffic 14: 551-567.

FALCONE FERREYRA, M.L., CASAS, M.I., QUESTA, J.I., HERRERA, A.L., DEBLA- 
SIO, S., WANG, J., JACKSON, D., GROTEWOLD, E. and CASATI, P. (2012). Evolution and expression of tandem duplicated maize flavonol synthase genes. Front Plant Sci 3: 101.

FANG, Y., HEARN, S. and SPECTOR, D.L. (2004). Tissue-specific expression and dynamic organization of SR splicing factors in Arabidopsis. Mol Biol Cell 15: 2664-2673.

FERNANDEZ, A.I., VIRON, N., ALHAGDOW, M., KARIMI, M., JONES, M., AMSELLEM, Z., SICARD, A., CZEREDNIK, A., ANGENENT, G., GRIERSON, D. et al., (2009). Flexible tools for gene expression and silencing in tomato. Plant Physiol 151: 1729-1740.

FIELD, J.J., CARRILES, R., SHEETZ, K.E., CHANDLER, E.V., HOOVER, E.E., TILLO, S.E., HUGHES, T.E., SYLVESTER, A.W., KLEINFELD, D. and SQUIER, J.A. (2010). Optimizing the fluorescent yield in two-photon laser scanning microscopy with dispersion compensation. Opt Express 18: 13661-13672.

FRICKER, M., RUNIONS, J. and MOORE, I. (2006). Quantitative fluorescence microscopy: From art to science. Annu Rev Plant Biol 57: 79-107.

GARDNER, M.J., BAKER, A.J., ASSIE, J.M., POETHIG, R.S., HASELOFF, J.P. and WEBB, A.A. (2009). GAL4 GFP enhancer trap lines for analysis of stomatal guard cell development and gene expression. J Exp Bot 60: 213-226.

GOEDHART, J., HINK, M.A., VISSER, A.J.W.G., BISSELING, T. and GADELLA, T.W.J. (2000). In vivo fluorescence correlation microscopy (FCM) reveals accumulation and immobilization of Nod factors in root hair cell walls. Plant $J$ 21: 109-119.

GOLDSHMIDT, A., ALVAREZ, J.P., BOWMAN, J.L. and ESHED, Y. (2008). Signals derived from YABBY gene activities in organ primordia regulate growth and partitioning of Arabidopsis shoot apical meristems. Plant Cell 20: 1217-30.

GOLL, M.G., ANDERSON, R., STAINIER, D.Y., SPRADLING, A.C. and HALPERN, M.E. (2009). Transcriptional silencing and reactivation in transgenic zebrafish. Genetics 182: 747-755.

GRIESBECK, O., BAIRD, G.S., CAMPBELL, R.E., ZACHARIAS, D.A. and TSIEN, R.Y. (2001). Reducing the environmental sensitivity of yellow fluorescent protein - Mechanism and applications. J Biol Chem 276: 29188-29194.

GROSSMANN, G., MEIER, M., CARTWRIGHT, H.N., SOSSO, D., QUAKE, S.R., EHRHARDT, D.W. and FROMMER, W.B. (2012). Time-lapse fluorescence imaging of Arabidopsis root growth with rapid manipulation of the root environment using the RootChip. J Vis Exp 65: e4290.

GUTIERREZ, R., LINDEBOOM, J.J., PAREDEZ, A.R., EMONS, A.M. and EHRHARDT, D.W. (2009). Arabidopsiscortical microtubules position cellulose synthase delivery to the plasma membrane and interact with cellulose synthase trafficking compartments. Nat Cell Biol 11: 797-806.

HAN, J.J., JACKSON, D. and MARTIENSSEN, R. (2012). Pod Corn Is Caused by Rearrangement at the Tunicate1 Locus. Plant Cell 24: 2733-2744.

HANSON, M., KWOK, E., REISEN, D., ISHIDA, H., HOLZINGER, A. and KOHLER, R. (2007). Dynamic morphology of plastids and stromules in angiosperm plastids. Photosynth Res 91: 274-274

HARPER, B.K., MABON, S.A., LEFFEL, S.M., HALFHILL, M.D., RICHARDS, H.A., MOYER, K.A. and STEWART, C.N. (1999). Green fluorescent protein as a marker for expression of a second gene in transgenic plants. Nature Biotechnol 17: 1125-1129.

HASELOFF, J., SIEMERING, K.R.,PRASHER, D.C. and HODGE, S. (1997). Removal of a cryptic intron and subcellular localization of green fluorescent protein are required to mark transgenic Arabidopsis plants brightly. Proc Nat Nat Acad Sci USA 94: 2122-2127.

HARTER, K., MEIXNER, A.J. and SCHLEIFENBAUM, F. (2012). Spectro-microscopy of living plant cells. Mol Plant 5: 14-26.

HEISLER, M.G., HAMANT, O., KRUPINSKI, P., UYTTEWAAL, M., OHNO, C., JONSSON, H., TRAAS, J. and MEYEROWITZ, E.M. (2010). Alignment between PIN1 polarity and microtubule orientation in the shoot apical meristem reveals a tight coupling between morphogenesis and auxin transport. PLoS Biol 8: e1000516.

HINK, M.A., BISSELIN, T. and VISSER, A.J. (2002). Imaging protein-protein interactions in living cells. Plant Mol Biol 50: 871-883.

HINK, M.A., BORST, J.W. and VISSER, A.J. (2003). Fluorescence correlation spectroscopy of GFP fusion proteins in living plant cells. Methods Enzymo/361:93-112.

HOOVER, E.E., YOUNG, M.D., CHANDLER, E.V., LUO, A., FIELD, J.J., SHEETZ, K.E., SYLVESTER, A.W. and SQUIER, J.A. (2010). Remote focusing for programmable multi-layer differential multiphoton microscopy. Biomed Opt Express 2: 113-122.

HU, W. and CHENG, C.L. (1995). Expression of Aequorea Green Fluorescent Protein in Plant-Cells. FEBS Letters 369: 331-334.

HUMPHRIES, J.A., VEJLUPKOVA, Z., LUO, A., MEELEY, R.B., SYLVESTER, A.W., FOWLER, J.E. and SMITH, L.G. (2011). ROP GTPases act with the receptor-like protein PAN1 to polarize asymmetric cell division in maize. Plant Cell23:2273-2284.

IMMINK, R.G.H., GADELLA, T.W.J., FERRARIO, S., BUSSCHER, M. and ANGENENT, G.C. (2002). Analysis of MADS box protein-protein interactions in living plant cells. Proc Nat Nat Acad Sci USA 99: 2416-2421.

JACKSON, D. (2002). Double labeling of KNOTTED1 mRNA and protein reveals multiple potential sites of protein trafficking in the shoot apex. Plant Physiol 129: 1423-1429.

JONES, A.M., EHRHARDT, D.W. and FROMMER, W.B. (2012). A never ending race for new and improved fluorescent proteins. BMC Biology 10: 39.

JONES, W.D. (2009). The expanding reach of the GAL4/UAS system into the behavioral neurobiology of Drosophila. BMB REP 42: 705-712.

KIRIENKO, D.R., LUO, A. and SYLVESTER, A.W. (2012). Reliable transient transformation of intact maize leaf cells for functional genomics and experimental study. Plant Physiol 159: 1309-1318.

KOHLER, R.H., SCHWILLE, P., WEBB, W.W. and HANSON, M.R. (2000). Active protein transport through plastid tubules: velocity quantified by fluorescence correlation spectroscopy. J Cell Sci 113: 3921-3930.

KREBS, M., HELD, K., BINDER, A., HASHIMOTO, K., DEN HERDER, G., PARNISKE, M., KUDLA, J. and SCHUMACHER, K. (2012). FRET-based genetically encoded sensors allow high-resolution live cell imaging of $\mathrm{Ca}^{2+}$ dynamics. Plant J69: 181-192.

KWOK, E.Y. and HANSON, M.R. (2004). GFP-labelled Rubisco and aspartate aminotransferase are present in plastid stromules and traffic between plastids. $J$ Exp Bot 55: 595-604.

LEE, B.H., JOHNSTON, R. YANG, Y., GALLAVOTTI, A., KOJIMA, M., TRAVENÇOLO, B.A., COSTA, L.F., SAKAKIBARA,H. AND JACKSON, D. (2009). Studies of aberrant phyllotaxy1 mutants of maize indicate complex interactions between auxin and cytokinin signaling in the shoot apical meristem. Plant Physiol 150: 205-216.

LINDEBOOM, J.J., LIOUTAS, A., DEINUM, E.E., TINDEMANS, S.H., EHRHARDT, D.W., EMONS, A.M., VOS, J.W. and MULDER, B.M. (2013). Cortical microtubule arrays are initiated from a nonrandom prepattern driven by atypical microtubule initiation. Plant Physiol 161: 1189-1201.

LIPPINCOTT-SCHWARTZ, J. and PATTERSON, G.H. (2003). Development and use of fluorescent protein markers in living cells. Science 300: 87-91.

LUU, D.T., MARTINIERE, A., SORIEUL, M., RUNIONS, J. and MAUREL, C. (2012). Fluorescence recovery after photobleaching reveals high cycling dynamics of plasma membrane aquaporins in Arabidopsis roots under salt stress. Plant $J$ 69: 894-905.

MATHUR, J., GRIFFITHS, S., BARTON, K. and SCHATTAT, M.H. (2012). Greento-red photoconvertible mEosFP-aided live imaging in plants. Methods Enzymol 504: 163-181.

MENG, X., MUSZYNSKI, M.G. and DANILEVSKAYA, O.N. (2011). The FT-Like ZCN8 gene functions as a floral activator and is involved in photoperiod sensitivity in maize. Plant Cell 23: 942-960.

MESETH, U., WOHLAND, T., RIGLER, R. and VOGEL, H. (1999). Resolution of fluorescence correlation measurements. Biophys/ J 76: 1619-1631.

MIYAWAKI, A. (2011). Development of Probes for Cellular Functions Using Fluorescent Proteins and Fluorescence Resonance Energy Transfer. Annu Rev Biochem 80: 357-373

MOHANTY, A., LUO, A., DEBLASIO, S., LING, X.Y., YANG, Y., TUTHILL, D.E., WILLIAMS, K.E., HILL, D., ZADROZNY, T., CHAN, A. et al., (2009). Advancing Cell Biology and Functional Genomics in Maize Using Fluorescent Protein-Tagged Lines. Plant Physiol 149: 601-605.

MOORE, I., SAMALOVA, M. and KURUP, S. (2006). Transactivated and chemically inducible gene expression in plants. Plant $J$ 45: 651-683.

MORENO, M.A., HARPER, L.C., KRUEGER, R.W., DELLAPORTA, S.L. and FREELING, M. (1997). liguleless1 encodes a nuclear-localized protein required for induction of ligules and auricles during maize leaf organogenesis. Genes Dev 11: 616-628.

MUTO, H., KINJO, M. and YAMAMOTO, K.T. (2009). Fluorescence cross-correlation spectroscopy of plant proteins. Methods Mol Biol 479: 203-215.

MUTO, H., NAGAO, I., DEMURA, T., FUKUDA, H., KINJO, M. and YAMAMOTO, K.T. (2006). Fluorescence cross-correlation analyses of the molecular interac- 
tion between an Aux/IAA protein, MSG2/IAA19, and protein-protein interaction domains of auxin response factors of Arabidopsis expressed in HeLa cells. Plant Cell Physiol 47: 1095-1101.

NEHLS, S., SNAPP, E.L., COLE, N.B., ZAAL, K.J.M., KENWORTHY,A.K., ROBERTS, T.H., ELLENBERG, J., PRESLEY, J.F., SIGGIA, E. and LIPPINCOTT-SCHWARTZ, J. (2000). Dynamics and retention of misfolded proteins in native ER membranes. Nature Cell Biol 2: 288-295.

NIEDZ, R.P., SUSSMAN, M.R. and SATTERLEE, J.S. (1995). Green Fluorescent Protein - an in-Vivo Reporter of Plant Gene-Expression. Plant Cell Rep 14:403-406.

REDDY, G.V., GORDON, S.P. and MEYEROWITZ, E.M. (2007). Unravelling developmental dynamics: transient intervention and live imaging in plants. Nature Rev Mol Cell Biol 8: 491-501.

RIZZO, M.A., DAVIDSON, M.W. and PISTON, D.W. (2009). Fluorescent protein tracking and detection: applications using fluorescent proteins in living cells. Cold Spring Harb Protoc 12: pdb top64.

RIZZO, M.A., SPRINGER, G.H., GRANADA, B. and PISTON, D.W. (2004). An improved cyan fluorescent protein variant useful for FRET. Nature Biotech. 22: 445-449.

RUNIONS, J., BRACH, T., KUHNER, S. and HAWES, C. (2006). Photoactivation of GFP reveals protein dynamics within the endoplasmic reticulum membrane. $J$ Exp Bot 57: 43-50.

RUTHERFORD, S., BRANDIZZI, F., TOWNLEY, H., CRAFT, J., WANG, Y.B., JEPSON, I., MARTINEZ, A. and MOORE, I. (2005). Improved transcriptional activators and their use in mis-expression traps in Arabidopsis. Plant $J$ 43: 769-788.

ROBINSON, S., BARBIERDE REUILLE, P., CHAN, J., BERGMANN, D., PRUSINKIEWICZ, P. and COEN, E. (2011). Generation of spatial patterns through cell polarity switching. Science 333: 1436-1440.

SAMALOVA, M., BRZOBOHATY, B. and MOORE, I. (2005). pOp6/LhGR: a stringently regulated and highly responsive dexamethasone-inducible gene expression system for tobacco. Plant J 41: 919-935.

SAMPATHKUMAR, A., LINDEBOOM, J.J., DEBOLT, S., GUTIERREZ, R., EHRHARDT, D.W., KETELAAR, T. and PERSSON, S. (2011). Live cell imaging reveals structural associations between the actin and microtubule cytoskeleton in Arabidopsis. Plant Cell 23: 2302-2313.

SATTARZADEH, A., FULLER, J., MOGUEL, S., WOSTRIKOFF, K., SATO, S., COVSHOFF, S., CLEMENTE, T., HANSON, M. and STERN, D.B. (2009). Transgenic maize lines with cell-type specific expression of fluorescent proteins in plastids. Plant Biotechnol J 8: 112-125.

SCHWILLE, P., MEYERALMES, F.J. and RIGLER, R. (1997). Dual-color fluorescence cross-correlation spectroscopy for multicomponent diffusional analysis in solution. Biophys J 72: 1878-1886.

SEGAL, G., SONG, R.T. and MESSING, J. (2003). A new opaque variant of maize by a single dominant RNA-interference-inducing transgene. Genetics 165: 387-397.

SHANER, N.C., CAMPBELL, R.E., STEINBACH, P.A., GIEPMANS, B.N., PALMER, A.E. and TSIEN, R.Y. (2004). Improved monomeric red, orange and yellow fluorescent proteins derived from Discosoma sp. red fluorescent protein. Nature Biotech. 22: 1567-72.

SHANER, N.C., LIN, M.Z., MCKEOWN, M.R., STEINBACH, P.A., HAZELWOOD, K.L., DAVIDSON, M.W. and TSIEN, R.Y. (2008). Improving the photostability of bright monomeric orange and red fluorescent proteins. Nat Methods 5: 545-551.

SHANER, N.C., STEINBACH, P.A. and TSIEN, R.Y. (2005). A guide to choosing fluorescent proteins. Nat Methods 2: 905-909.

SHEEN, J., HWANG, S.B., NIWA, Y., KOBAYASHI, H. and GALBRAITH, D.W. (1995) Green-fluorescent protein as a new vital marker in plant cells. Plant J 8: 777-784.

SHIMOMURA, O., JOHNSON, F.H. and SAIGA, Y. (1962). Extraction, purification and properties of aequorin, a bioluminescent protein from luminous Hydromedusan, Aequorea. J Cell Physiol 59: 223-239.

SRILUNCHANG, K.O., KROHN, N.G. and DRESSELHAUS, T. (2010). DiSUMO-like DSUL is required for nuclei positioning, cell specification and viability during female gametophyte maturation in maize. Development 137: 333-345.

STAHL, Y., GRABOWSKI, S., BLECKMANN, A., KUHNEMUTH, R., WEIDTKAMPPETERS, S., PINTO, K.G., KIRSCHNER, G.K., SCHMID, J.B., WINK, R.H., HULSEWEDE, A. et al., (2013). Moderation of Arabidopsis root stemness by CLAVATA1 and ARABIDOPSIS CRINKLY4 receptor kinase Complexes. Curr Biol 23: 362-371.

STAEHELIN, L.A. (1997). The plant ER: a dynamic organelle composed of a large number of discrete functional domains. Plant J 11: 1151-1165.

SUBACH, O.M., GUNDOROV, I.S., YOSHIMURA, M., SUBACH, F.V., ZHANG, J., GRUENWALD, D., SOUSLOVA, E.A., CHUDAKOV, D.M. and VERKHUSHA, V.V. (2008). Conversion of red fluorescent protein into a bright blue probe. Chem Biol 15: 1116-1124.

SUN, Y., BOOKER, C.F., KUMARI, S., DAY, R.N., DAVIDSON, M. and PERIASAMY A. (2009). Characterization of an orange acceptor fluorescent protein for sensitized spectral fluorescence resonance energy transfer microscopy using a white-light laser. J Biomed Opt 14: 054009

TEH, O.K., SHIMONO, Y., SHIRAKAWA, M., FUKAO, Y., TAMURA, K., SHIMADA, T. and HARA-NISHIMURA, I. (2013). The AP-1 mu Adaptin is Required for KNOLLE Localization at the Cell Plate to Mediate Cytokinesis in Arabidopsis. Plant Cell Physiol doi: 54: 838-847.

TSIEN, R.Y. (1998). The green fluorescent protein. Annu Rev Biochem 80 67: 509-44.

TSIEN, R.Y. (2009). Constructing and exploiting the fluorescent protein paintbox (Nobel Lecture). Angew Chem Int Ed Engl 48: 5612-5626.

WALLRABE, H. and PERIASAMY, A. (2005). Imaging protein molecules using FRET and FLIM microscopy. Curr Opin Biotechnol 16: 19-27.

WARD, T.H. and BRANDIZZI, F. (2004). Dynamics of proteins in Golgi membranes: comparisons between mammalian and plant cells highlighted by photobleaching techniques. Cell Mol Life Sci61: 172-185.

WHIPPLE, C.J., HALL, D.H., DEBLASIO, S., TAGUCHI SHIOBARA, F., SCHMIDT, R.J. AND JACKSON, D. (2010). A conserved mechanism of bract suppression in the grass family. Plant Cell 22: 538- 538

WHIPPLE, C.J., KEBROM, T.H., WEBER, A.L., YANG, F., HALL, D., MEELEY, R. SCHMIDT, R., DOEBLEY, J., BRUTNELL, T.P. and JACKSON, D. (2011). grassy tillers 1 promotes apical dominance in maize and responds to shade signals in the grasses. Proc Nat Nat Acad Sci USA 108: E506-E512.

YANG, Y.D., ELAMAWI, R., BUBECK, J., PEPPERKOK, R., RITZENTHALER, C. and ROBINSON, D.G. (2005). Dynamics of COPII vesicles and the Golgi apparatus in cultured Nicotiana tabacum BY-2 cells provides evidence for transient association of Golgi stacks with endoplasmic reticulum exit sites. Plant Cell 17: 1513-1531.

ZELAZNY, E., BORST, J.W., MUYLAERT, M., BATOKO, H., HEMMINGA, M.A. and CHAUMONT, F. (2007). FRET imaging in living maize cells reveals that plasma membrane aquaporins interact to regulate their subcellular localization. Proc Nat Nat Acad Sci USA 104: 12359-12364.

ZHANG, J., MARTIN, J.M., BEECHER, B., MORRIS, C.F., CURTIS HANNAH, L. and GIROUX, M.J. (2009). Seed-specific expression of the wheat puroindoline genes improves maize wet milling yields. Plant Biotechnol J 7: 733-743.

ZHANG, X., FACETTE, M., HUMPHRIES, J.A., SHEN, Z., PARK, Y., SUTIMANTANAPI, D., SYLVESTER, A.W., BRIGGS, S.P. and SMITH, L.G. (2012). Identification of PAN2 by quantitative proteomics as a leucine-rich repeat-receptor-like kinase acting upstream of PAN1 to polarize cell division in maize. Plant Cell 24: 4577-4589. 


\section{Further Related Reading, published previously in the Int. J. Dev. Biol.}

Lessons from a search for leaf mutants in Arabidopsis thaliana

José Manuel Pérez-Pérez, Héctor Candela, Pedro Robles, Víctor Quesada, María Rosa Ponce and José Luis Micol

Int. J. Dev. Biol. (2009) 53: 1623-1634

Arabidopsis monomeric G-proteins, markers of early and late events in cell differentiation Mariette Bedhomme, Chantal Mathieu, Amada Pulido, Yves Henry and Catherine Bergounioux Int. J. Dev. Biol. (2009) 53: 177-185

The role of ion fluxes in polarized cell growth and morphogenesis: the pollen tube as an experimental paradigm

Erwan Michard, Filipa Alves and José A. Feijó

Int. J. Dev. Biol. (2009) 53: 1609-1622

Epidermal differentiation: trichomes in Arabidopsis as a model system Swen Schellmann and Martin Hülskamp Int. J. Dev. Biol. (2005) 49: 579-584

Young microspore-derived maize embryos show two domains with defined features also present in zygotic embryogenesis.

Pilar S Testillano, Carmen Ramírez, Jezabel Domenech, Maria-José Coronado, Phillipe Vergne, Elisabeth Matthys-Rochon and María C Risueño

Int. J. Dev. Biol. (2002) 46: 1035-1047

5 yr ISI Impact Factor $(2011)=2.959$
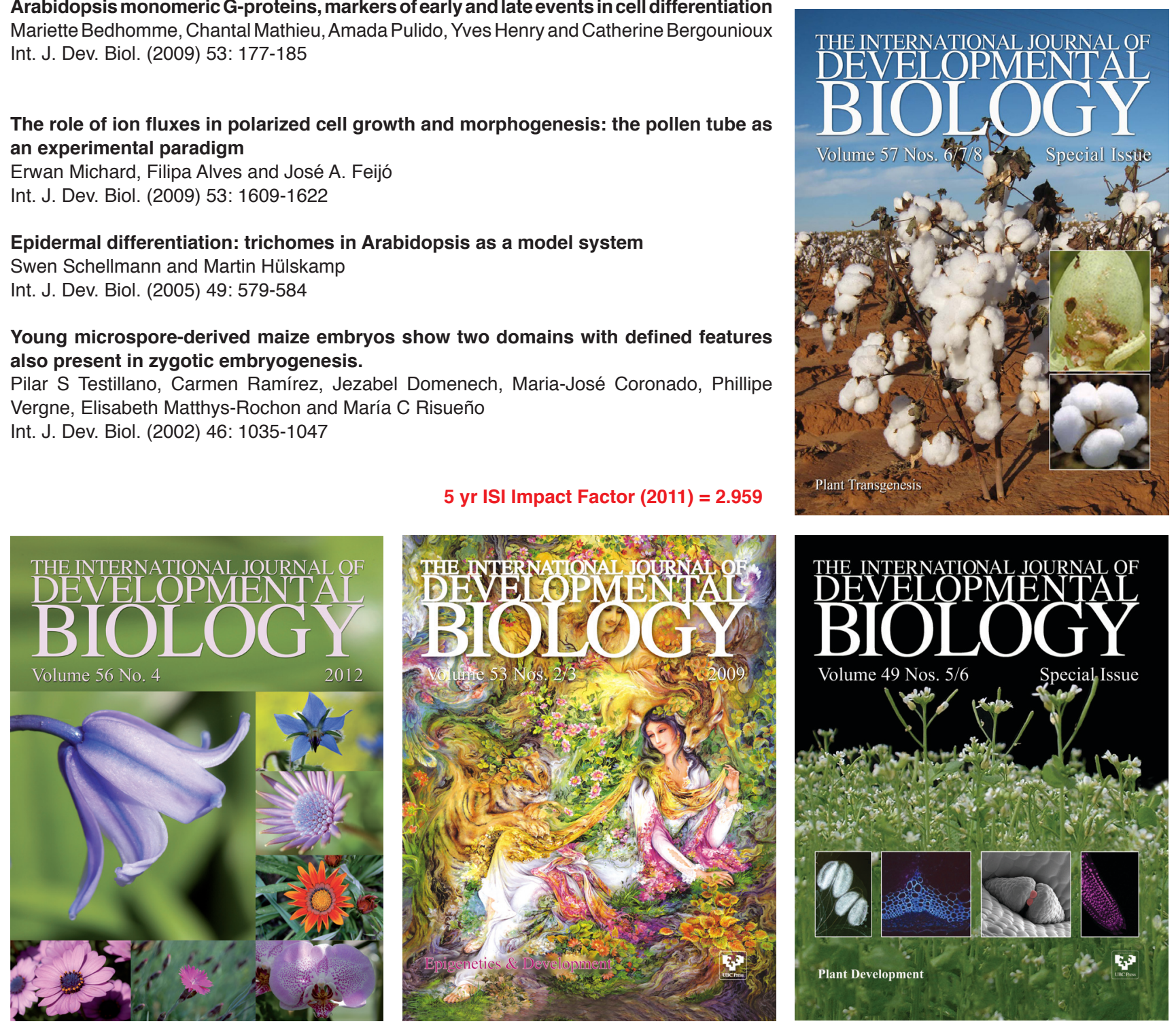